\title{
Research on Motives of China's Massive Direct Investment in the United States during the Post-Crisis Era
}

\author{
Zongbin Zhang ${ }^{1} \&$ Xiaofeng Liu ${ }^{1}$ \\ ${ }^{1}$ Economic School, Shandong Normal University, Jinan, Shandong, China \\ Correspondence: Xiaofeng Liu, Economic School, Shandong Normal University, Jinan, Shandong, China. \\ E-mail: weconsensus@163.com
}

Received: July 17, 2015

doi:10.5539/ijef.v7n8p294
Accepted: July 29, 2015

Online Published: July 30, 2015

URL: http://dx.doi.org/10.5539/ijef.v7n8p294

\begin{abstract}
This paper is based on the modified eclectic theory of international production. According to the quarterly data after the US subprime crisis, this paper analyzes the factors that influence the direct investment from China to the United States using regression analysis. The result is as follows: China's and US's economic growth, development of the US science and technology, increase of energy production and aggravation of Sino-US trade friction have a positive effect on promoting China's massive direct investment to the United States while the exchange rate of USD against RMB has an opposite effect. According to the result, this article proposes some policy recommendations for the current situation of Chinese direct investment in the United States.
\end{abstract}

Keywords: the post-crisis era, direct investment to the United States, motives

\section{Introduction}

Since the 21st century's coming, especially after the US subprime crisis, economic globalization has been further deepened. In this post-crisis era, the world's economies are related more closely. As the world market becomes more and more open, most counties are seeking opportunities to develop long and stably through using both the external and internal markets actively. Early in the 1980s, China has realized the importance of opening up, but subjecting to the level of Chinese economic development, economic system and so on, China's achievement in the world market is only limited to the development of commodity export and the capital outflow is unsatisfied. In other words, to a great extent, China was a destination for foreign capital inflows, while its outward foreign direct investment was "blank". After joining the WTO, the level of China's opening up has been increased largely, so the foreign direct investment as China's "going out" strategy is becoming more and more important. Facing with RMB appreciation, the gradual disappearance of the demographic dividend, the growing trade friction with developed countries and many other problems, outward foreign direct investment will undoubtedly become the best choice to solve those deep-seated problems, and have great significance and far-reaching impact for enterprises to be adapted to transnational production and operation, seek a broader market and improve their international competitiveness.

As we all know, China's outward foreign direct investment started late, and show little interest on developed economies. However, since the 2008 financial crisis swept the globe, the trade, investment and other economic barometers of the developed countries such as United States have continued to slump, even fall sharply. While at the same time outward foreign direct investment from developing countries especially China have been expanding rapidly, especially to the United States and other developed countries. Why do China carry out such large-scale direct investment to the United States during the post-crisis era? Does this mean that capital flow has changed from developed-to-developing-country mode to the opposite mode that is developing-to-developed-country mode? Such problems attracted the attention of many experts because studying them has great theoretical and practical significance. At present, the scholars have made some exploratory research. Yiling Huang (2011) analyzed the driving forces of Chinese multinational corporation's direct investment into the United States, and concluded that through investing in the United States, China can promote their own companies' international development, and narrow the technology gap between China and the United States and also can break the US sensitive high-tech embargo; Shan Jia (2011) used the flow data of US manufacturing investment from China to make regression analysis, drawing the conclusion that the existence of trade barriers has impact on Chinese direct investment into the United States; Shunqi Ge, Daying Yan (2012) 
described the driving forces of China's outward foreign direct investment from three aspects that are domestic enterprise, macroeconomic factors and the investment environment in the United States; Bo Peng (2013) verified the affecting factors and its proportion of Chinese direct investment in the United States by quantitative analysis and proposed strategies to expand direct investment in the United States; Junjiang Li, Chunlong Xue, Benye Shi (2013) summarized the internal motivations of China's direct investment in the United States into five points which are as follows: obtaining large merchandising markets, buying strategic assets, improving Chinese enterprises' cross-border operational efficiency, economic mode transformation, RMB appreciation and the increase of foreign exchange reserves. Sha Li (2013) studied the influential factors of reverse technology spillover effect of Chinese direct investment in the United States from the perspective of different ways. The Factors are as follows: R\&D capital stock of both China and America, human capital situation of China and America, the level of informatization of China and America and American Patent Application Condition. Pingping Wang (2013) believes that Chinese enterprises' direct investment in the United States is led by government. There are five factors that triggered China's large-scale direct investment in America, including China's excessive foreign exchange reserve, appreciation expectation of RMB, high profits attraction in the United States, seeking high technology, escaping from the high-tech embargo from America and easing the Sino-US trade imbalance. Wenjing $\mathrm{Li}$ (2014) analyzes the political and economic factors that influence China's direct investment to the US in detail from the aspect of investing country and the host country. Zhenyu Ge, Yong Zhan (2015) made an empirical study on the factors that affect China's direct investment to US, and the results shows that the development of the US economy, market scale and high technology have the biggest attraction for China's OFDI and the increase of exports to the US also have the role in promoting China's OFDI. Yuanpeng Zhang (2015) studied that after the global financial crisis, what the main affecting factors on China's large-scale direct investment in the US are the decrease of US asset prices and trading opportunities because of the crisis, the Chinese government "going out" strategy's promotion, the Sino-US trade frictions, China domestic market transformation and the development of management ability of Chinese enterprises' internationalization. These studies are mostly on the qualitative analysis of China's OFDI in the US, and lack of quantitative analysis, ignoring the situation after the crisis. And this article is to make up for the shortcomings of the above documents, based on the modified eclectic theory of international production, according to quarterly data of China's direct investment flows to the United States and the six motives to make regression, it carried out a more detailed study on motives of China's massive direct investment in the United States during the post-crisis era from both theoretical and empirical aspect.

\section{The Status of China's Direct Investment in US in the Post-Crisis Era}

Since the reform and opening up, the characteristic of Sino-US direct investment is there is a sole investment direction which is from United States to China. However, a new trend about China and the US investment mode appeared after the global crisis: China began to accelerate the direct investment in the US, with the scale of investment expanding each year. According to Chinese statistics, before 2003 the stock of direct investment from China to US is only $\$ 500$ million. In the year 2007, after experiencing modest growth, the stock of direct investment from China to US reaches \$ 1.881 billion. Since 2008, China's direct investment in the United States grew rapidly. In 2013 the stocks of China's direct investment in US soared to $\$ 21.89$ billion. Table 1 shows the stock of China's direct investment in the United States in recent years.

Table 1. 2003-2013 the stock of China's direct investment in the US (US \$ billion)

\begin{tabular}{cccccccccccc}
\hline Year & 2003 & 2004 & 2005 & 2006 & 2007 & 2008 & 2009 & 2010 & 2011 & 2012 & 2013 \\
\hline Stock & 5 & 6.65 & 8.23 & 12.38 & 18.81 & 23.9 & 33.38 & 48.74 & 89.93 & 170.8 & 218.9 \\
\hline
\end{tabular}

Source: Statistical Bulletin of China's foreign direct investment.

According to the Rhodium Group statistics, China's direct investment in the United States was up to $\$ 47.5$ billion last year. Although statistical standard of the two statistics is slightly different, the two statistics reflect very consistent trend that after the crisis, China's direct investment in the United States is developing at a strong growth rate, as shown in Figure 1. 


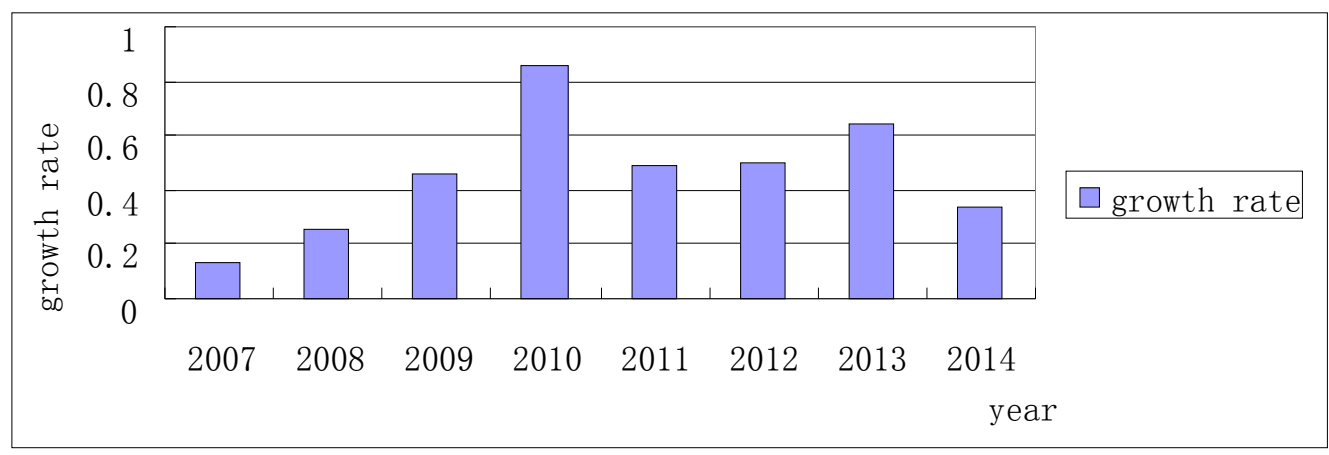

Figure 1. The annual growth rate of China's direct investment stock in the US

Data source: The Rhodium Group (http://rhg.com/interactive/China-investment-monitor).

At present, China's direct investment in the United States has the following characteristics:

First, it has a low starting point but grow rapidly. China's foreign direct investment mainly flowed to developing countries and those that flowed to the United States and other developed capital markets were little before. Until 2013, the stock of China's direct investment in the US is only slightly more than 20 billion dollars which only accounting for a relative small proportion in the whole foreign direct investment flowed into the United States. But since 2007, the number of direct investment projects in the US from China increasing rapidly, and the total investment nearly doubled every year. In 2010, Chinese companies in the United States carried out 65 direct investment projects, and its total investment was about $\$ 5.4$ billion. By 2013, Chinese companies have made a substantial increase in cross-border M \& A activity, and United States become one of the main acquisition targets countries for China. Among these Chinese companies, Shuanghui Abc International Holdings Ltd invested \$7.1 billion and made acquisition of Smithfield Foods, NYSE: SFD, which is the largest oversea direct investment for China. Therefore, although China's direct investment in the US is on a low level, it has the significant growth, and there will be much room for its development in the future.

Second, the industries and the areas that China's enterprise entered in US are not various. As the industry distribution of Chinese direct investment in US since 2011 shows, 2.327 billion dollars flowed to $\mathrm{m}$ manufacturing sector which therefore ranked first, accounting for above forty percent of Chinese direct investment in the United States. However, the statistics report released by the Rhodium Group pointed out that in 2014 some new features appeared in Chinese companies' investing industry in the US. The scale of investment in information and communication technology has become the largest, reaching $\$ 5.75$ billion. What's more, the number areas that China's investments enter increase significantly in 2014. By the end of 2014, Chinese companies in the United States have has 1,583 agencies distributed throughout the United States.

Third, the subjects that carry out investments are various but the ways are simple. The subjects varied from small and medium private enterprises to large state-owned enterprises. The number of the projects carried out by private enterprises' accounts for $75 \%$ of the total projects, which has played a big role in promoting Chinese enterprises to practice "going out" strategy. Meanwhile, state-owned enterprises have also made great contribution. According to the monitoring network data of Chinese investment in the US, by the second quarter of 2012, state-owned enterprises finished 157 projects totally, having cumulative net investment of $\$ 13.164$ billion, far higher than private enterprises' $\$ 7.745$ billion after the completion of 434 projects. Therefore as far as the number of projects is concerned, the private enterprises looked more powerful. But as far as investment volume is concerned, the state-owned enterprises had their advantage. But the situation has changed in 2014, 76 percents of Chinese investment projects in the US and 81 percents of the amount invested in the US are both from private enterprises. And whether it is private or state-owned enterprises, the way China direct investment in the US is based on mergers and acquisitions.

\section{Theoretical Basis of China Direct Investment in the US in the Post-Crisis Era}

\subsection{The Modified Eclectic Theory of International Production}

Professor John Harry Dunning published the paper "Trade, Location of Economic Activity and the Multinational Enterprise: A Search for an Eclectic Approach" in 1977, presenting the eclectic theory of international production namely OLI theory. In this theory, ownership advantages are certain patents, technology and intellectual property that an enterprise owns. Location advantages means the host country has possessed some 
advantages, such as a large market, tax incentives. As the mother country's ownership advantages and the host country's location advantages are statically measurable, internalization advantages refers the dynamic earnings brought to an enterprise after internalizing the external market for a specific period. We can understand that ownership advantages and regional advantages are interdependent. And therefore once host country is determined, the location advantage will be immediately identified and the ownership advantages of the home country is relatively determined too and internalization advantages can accordingly be measured. So location factors are very important in foreign direct investment. Based on the above analysis, this paper is targeted on the motives of China's direct investment in the US. The United States is determined as the host country, thus geographical advantages are relatively clear. At the same time, internalization is used to avoid market risks, then to enhance corporate ownership advantages. Therefore the original theory of three factors can be combined into two factors, namely location and ownership advantages (internalization factor was seen as as an endogenous variables of ownership factor). Location advantages can be understood as "the host country's pull" of China's large-scale direct investment into the United States, while ownership advantages can be understood as "the home country's push" of China's direct investment in the US.

\section{2 "Host Country's Pull" of Chinese Direct Investment in the United States}

Firstly we consider technology pull. As we all know, the United States holds the world's most highly sophisticated technology. US companies attach importance to innovation, and therefore the United States is ahead of many countries in technology. In 2013, the United States is the best in terms of the number of patents. And innovation requires talent and talent is based on education. According to statistics, about 20 percent of the study carried out by American universities was funded by the National Science Foundation. The total amount of funding provided in 2013 has already reached $\$ 7.08$ billion, despite a slight decrease in 2014, but it still reached more than $\$ 6.6$ billion. So because of paying much attention to education, nurturing talent and encouraging innovation, US attracted the interest of companies from all over the world. Since foreign direct investment is an important way of international production and management for enterprises, through the efficient allocation of global capital, enterprises can obtain the advantages of other global resources. Therefore, under the background that the economic globalization is deepening, more and more Chinese enterprises seized the opportunity to carry out direct investment in developed countries to obtain the US and other countries' advanced technology and international management experience through their direct investment, and continued to optimize their own organizational structure and improve their international competitiveness. On the one hand, Chinese companies can take advantage of the US local talents and advanced equipment to carry out scientific and technological research. On the other hand, through the acquisition of the United States' high-tech enterprises, we will transfer its advanced technology back to our home country, promoting the national economy innovation, development and upgrading domestic enterprises.

Secondly we consider resources pull. OLI theory believes that transnational corporations' foreign direct investment was related to the host country's endowment of natural resources. US shale gas revolution has made the United States as the only country to achieve large-scale commercial shale gas exploitation. According to relevant data, the US shale gas production in 2006 only accounted for 1 percent of the gas production. In 2010 it grew to 20 percent, more than 100 billion cubic meters. The annual output continued to rise in 2013 to 3025 billion cubic meters, while in 2014 the US shale gas production reaches a new high point, 32.9 billion cubic feet per day. If this trend continues, the United States may be able to achieve energy independence, and even be expected to become LNG exporter in the future. Thus many Chinese companies see this profitable opportunity and focus on investment toward the US shale gas projects. On January 4, 2013, Lanzhou Haimo Technologies Co., Ltd became another company that invested US shale gas areas of business ever since China National Offshore Oil Corporation and Sinopec Group did, which means that China's private listing companies can also enter the American unconventional oil and gas exploration and development field successfully. Although energy investments are costly, obtaining the US related technology has far-reaching implications for the energy stability and national economic development of China. So, in recent years Chinese enterprises carrying out large-scale direct investment in the United States has a certain relationship with the attraction of US shale gas and other energy resources.

Thirdly we consider markets pull. The United States as the world's most developed capitalist country undoubtedly has the sound market environment and broad consumer groups. Cheng and Ma (2007) got the results by empirical research: economic scale of the host country can encourage China to carry out its direct investment, because one of the main motivations of foreign direct investment of Chinese enterprises is to open up overseas markets. In the 1990s, the size of the US economy had reached 700 billion dollars, in 2014 the US GDP was up to $\$ 1,741,830,000,000$, which means that the US is more and more attractive to Chinese companies' 
capital flows. Affected by factors of American sound market mechanism, faster market growth, etc, many Chinese enterprises invested in the United States by setting up factories to obtain and maintain a US high local market share. As the world's second-largest PC maker Lenovo PC company produced PC in North Carolina, although the cost of production is much higher than domestic, Lenovo can serve American corporate clients better and obtain a higher share of the local market.

Fourthly we consider trade friction evasion. According to David Ricardo's theory of comparative advantage, China's comparative advantage lies in the abundant and cheap labor, and the US comparative advantage lies in abundant capital, advanced technology. Therefore it is possible to generate trade which is complementary for the two countries. Because China exports labor-intensive products and US exports capital-intensive products, the trade surplus between the two countries has expanded each year. The United States employed trade protectionism for protecting its related industries, and began to frequently impose it on Chinese products in the name of anti-dumping, countervailing, which led to trade friction deterioration between China and the US. To avoid trade disputes with the United States, Taking the 1980s Japanese's successful experience that it through direct investment to ease trade friction for reference, Chinese companies can continue to optimize the export structure and improve product quality on the one hand, and on the other hand carried out direct investment in the United States actively, by setting up factories in the United States. Thus in this local-production and local-sale way, Chinese companies can avoid trade barriers, maximize corporate profits and ease trade friction.

\section{3 "Mother Country's Pull" of Direct Investment in the United States from China}

First, the pull from transformation of economic development mode. In earlier years, China's economic growth is mainly dependent on the stimulation of exports and investments. But with the change of domestic and international environment for development, China is actively seeking new growth drivers, namely to promote the establishment of the open economic development ways of innovation, growth linkage, integration of interests. China is committed to expanding domestic demand, pushing technological progress, optimizing and upgrading China's foreign trade structure and other initiatives to reduce the over-reliance on exports and investment. With the world's most extensive market and the most advanced science and technology, the United States has become one of the key natural choice for China to seek new economic development pattern. Chairman Xi Jinping has repeatedly stressed that we will unswervingly push forward reform and opening up and accelerate the transformation of economic development mode. This undoubtedly contributed to encourage more Chinese capital flow into a more perfect market to get higher returns.

Second, the pull from financial environment. On the one hand China has large foreign exchange reserves. According to the World Bank database statistics, in 2014 China's foreign exchange reserves were up to $\$ 3.843$ trillion, and in which 70 percent are dollar assets. After the financial crisis and in the background of USD's devaluation, the pressure that keeping such a high foreign exchange reserves not depreciating is getting harder. China urgently needs to expand direct investment into the United States to reduce the risk of foreign exchange's shrunk, and at the same time capital inflows into the US also contributes to the appreciation of USD. On the other hand, long-term trend of the RMB appreciation has adverse impact on Chinese exports, making the export price advantage relatively lost. However, it is undeniable that RMB appreciation increases Chinese enterprises' purchasing power in the United States, reducing the cost of the direct investment into US, thus providing strong financial support for the Chinese enterprises to conduct direct investment in the United States.

Third, the pull from industrial reconstruction. In the next decade, the industrial reconstruction will always be an important foundation for China's economic development. US subprime mortgage crisis triggered big changes in the global industries, and China conforms to this global trend, upgrading traditional manufacturing industries, cultivating new industries, and transferring outdated industries. Many domestic enterprises began to reconfigure their global production networks and promote the capital flow into the US. Especially after the crisis, some enterprises seize the opportunity that some US enterprises operated difficultly and implemented a large-scale cross-border mergers and acquisitions in the United States in order to achieve further adjustment of domestic industrial structure and rapid development.

\section{Empirical Analysis on China's Direct Investment in the US in the Post-Crisis Era}

\subsection{Data Selection and Data Sources}

In order to reflect the true reality of the situation on the Chinese direct investment in the United States more directly, the paper combines impact factors of direct investment proposed by domestic and foreign scholars and select the following variables: China's direct investment in the United States, the US' GDP, China's GDP, US trade deficit with China, the United States' R\&D investment, energy production as well as exchange rate of USD against RMB. Sample interval for each variable is 16 quarters from 2011 to 2014 , and the decision and the 
source of each variable is chosen as follows:

China's direct investment in the United States (FDIL). Because quarterly data of Chinese direct investment in the United States we can get is only flow data now, this paper takes China's direct investment flows in the United States as the dependent variable. The Data comes from the Rhodium Group China Investment Monitoring Network.

US' GDP (UGDP). According to empirical research made by Cheng and Ma (2007), The economic size of the host country can encourage China to carry out its direct investment. The GDP is a important indicator to measure of the country's economy of scale, thus this paper uses 16 quarters' GDP data of the United States to reflect the host country's market pull. The Data comes from the US Department of Commerce website.

China' GDP (CGDP). The transformation of China's economic growth mode and upgrading of industrial structure can effectively promote the growth of China's national economy. A well-developed national economy can help its companies carry out foreign investment. Thus we use China's 16-quarters' GDP data to reflect the restructuring pull of the home country. The Data comes from China Statistical Yearbook.

US trade deficit with China (TRADE). US trade deficit with China is a measure of the US and Chinese economic tightness. This paper reflects the dynamic role to avoid trade friction. The data comes from the US Department of Commerce Web site and we have done some calculation.

US R\&D investment (R\&D). This article uses it to reflect the technical pull of the host country. The data comes from the International Monetary Fund, Battelle, R\&D Magazine.

US energy production (UEP). This paper regards oil production as the representative of the United States because other energies' quarterly data is difficult to obtain, Wre select 16 quarterly data to reflect the energy pull of the host country. The data comes from the International Energy structure Web site.

Exchange rate of USD against RMB $(\mathrm{EXCH})$. To some extent, currency appreciation would increase the countries' purchasing power of its currency, and promote direct investment to other country. Therefore, this article uses the quarterly exchange rate of USD against RMB to reflect the financial environmental push of the home country. The data comes from the People's Bank of China website.

\subsection{Empirical Analysis Process and Results}

\subsubsection{Unit Root Test}

Empirical variables in this article are time-series data, therefore we use ADF test method to make stationary test for the above 7 time-series variables. Table 2 shows that the dependent variable and the explanatory variables are non-stationary, but the first-order difference is stationary, so variables are integrated of order one, and have co-integration test conditions. Then we make co-integration test for each explanatory variable and the explanatory variables to determine whether there are long-term stable relationship between them.

Table 2. ADF unit root test results

\begin{tabular}{ccccccc}
\hline Variable & Type of test & ADF test value & $1 \%$ threshold & $5 \%$ threshold & $10 \%$ threshold & Conclusion \\
\hline Ln FDIL & $(0, \mathrm{c}, 3)$ & -1.0627 & -4.2001 & -3.1754 & -2.7290 & unstable \\
$\Delta$ lnFDIL & $(0, \mathrm{c}, 3)$ & -7.5534 & -4.2001 & -3.1754 & -2.7290 & stable under 1\% level \\
Ln UGDP & $(\mathrm{t}, \mathrm{c}, 3)$ & -3.1835 & -4.8864 & -3.8290 & -3.3630 & unstable \\
$\Delta$ LnUGDP & $(\mathrm{t}, \mathrm{c}, 3)$ & -3.8520 & -4.9923 & -3.8753 & -3.3883 & stable under 10\% level \\
LnCGDP & $(0, \mathrm{c}, 3)$ & -2.0346 & -2.4001 & -3.1754 & -2.7290 & unstable \\
$\Delta$ LnCGDP & $(0, \mathrm{c}, 3)$ & -71.5264 & -4.2001 & -3.1754 & -2.7290 & stable under 1\% level \\
LnTRADE & $(0, \mathrm{c}, 3)$ & -0.9539 & -4.0044 & -3.0989 & -2.6904 & unstable \\
$\Delta$ LnTRADE & $(0, \mathrm{c}, 3)$ & -3.6165 & -4.1219 & -3.1449 & -2.7138 & stable under 5\% level \\
LnEXCH & $(\mathrm{t}, \mathrm{c}, 3)$ & -3.1089 & -4.9923 & -3.8753 & -3.3883 & unstable \\
$\Delta$ LnEXCH & $(\mathrm{t}, \mathrm{c}, 3)$ & -9.7863 & -5.2954 & -4.0082 & -3.4608 & stable under 1\% level \\
LnUEP & $(\mathrm{t}, \mathrm{c}, 3)$ & -2.7850 & -4.8001 & -3.7912 & -3.3423 & unstable \\
$\Delta$ LnUEP & $(\mathrm{t}, \mathrm{c}, 3)$ & -3.9810 & -4.9923 & -3.8753 & -3.3883 & stable under 5\% level \\
Ln R\&D & $(\mathrm{t}, \mathrm{c}, 3)$ & -1.5690 & -4.8001 & -3.7912 & -3.3423 & unstable \\
$\Delta$ LnR\&D & $(\mathrm{t}, \mathrm{c}, 3)$ & -3.7925 & -4.8864 & -3.8290 & -3.3630 & stable under10\% level \\
\hline
\end{tabular}




\subsubsection{Co-Integration Test}

Traditional regression requires variables be stationary time series. For a plurality of non-stationary time series variables which forming linear combinations of the variables may be stable, that is, between the non-stationary series there is co-integrated relationship, so there is a long-term stable equilibrium relationship between these sequences variables. Commonly used is Johansen co-integration, judging by the track statistics, and you can get a co-integration equation.

Table 3. Johansen co-integration test results

\begin{tabular}{|c|c|c|c|c|c|}
\hline & Hypothesized No. of CE(s) & Eigenvalue & Trace Statistic & 0.05 Critical Value & Prob.** \\
\hline \multirow{2}{*}{ LnUGDP \& LnFDIL } & None * & 0.883227 & 25.90042 & 15.49471 & 0.0010 \\
\hline & At most 1 & 0.010785 & 0.130125 & 3.841466 & 0.7183 \\
\hline \multirow{2}{*}{ LnCGDP \& LnFDIL } & None * & 0.982261 & 51.79956 & 15.49471 & 0.0000 \\
\hline & At most $1 *$ & 0.491880 & 7.447419 & 3.841466 & 0.0063 \\
\hline \multirow{2}{*}{ LnTRADE \& LnFDIL } & None * & 0.818311 & 19.61372 & 15.49471 & 0.0113 \\
\hline & At most 1 & 0.074672 & 0.853676 & 3.841466 & 0.3555 \\
\hline \multirow{2}{*}{ LnEXCH \& LnFDIL } & None * & 0.781888 & 19.87908 & 15.49471 & 0.0102 \\
\hline & At most 1 & 0.247567 & 3.128880 & 3.841466 & 0.0769 \\
\hline \multirow{2}{*}{ LnUEP \& LnFDIL } & None * & 0.963244 & 42.12215 & 15.49471 & 0.0000 \\
\hline & At most 1 & 0.186761 & 2.480759 & 3.841466 & 0.1152 \\
\hline \multirow{2}{*}{ Ln R\&D \& LnFDIL } & None $*$ & 0.999782 & 121.1594 & 15.49471 & 0.0001 \\
\hline & At most $1 *$ & 0.924411 & 28.40696 & 3.841466 & 0.0000 \\
\hline
\end{tabular}

From the above results we can see that at the 5 percent level of significance, there exists a long-term and stable relationship between the explained variables and the explanatory variables, and the co-integration equation is as follows:

$$
\begin{array}{ll}
\text { LnFDIL }=36.52 \ln U G D P+c ; & \text { LnFDIL }=10.09 \operatorname{lnCGDP}+c ; \\
\text { LnFDIL }=21.95 \ln \text { TRADE }+c ; & \text { LnFDIL }=-45.59 \operatorname{lnEXCH}+c ; \\
\text { LnFDIL }=7.91 \ln U E P+c ; & \text { LnFDIL }=28.91 \operatorname{lnR} \& D+c .
\end{array}
$$

We can get the conclusion that after the crisis, the most obvious motivation for China to launch large-scale direct investment in the United States is the rise of the exchange rate of USD against RMB, namely the appreciation of the RMB. Specifically, once the USD appreciates by one unit, China's direct investment in the United States will reduce by 45.59 units. The second motivation is US market pull. Once US gross domestic product increases by 1 unit, China's direct investment in the US will increase by 36.52 units. The third motivation is America technology pull. Once United States' R\&D investment increase by every one unit, China's direct investments in the United States will increase by 28.91 units. The forth motivation is the US trade deficit with China. Once the trade deficit increases by 1 unit, China's direct investment in the US will increase by 21.95 units. The attraction of China's own development and the United States energy is less prominent comparatively to the above motivations.

\subsubsection{Granger Causality Test}

Through the above co-integration test, we can obtain changes of dependent variable corresponding to the explanatory variables. To determine whether there is a causal relationship between them needs to make Granger causality test. 
Table 4. Granger causality test results

\begin{tabular}{ccc}
\hline NULL HYPOTHESIS & P VALUES & CONCLUSION \\
\hline LnUGDP does not Granger Cause LnFDIL & 0.0203 & accept \\
LnFDIL does not Granger Cause LnUGDP & 0.9918 & refuse \\
LnCGDP does not Granger Cause LnFDIL & 0.0107 & accept \\
LnFDIL does not Granger Cause LnCGDP & 0.0064 & accept \\
LnTRADE does not Granger Cause LnFDIL & 0.0645 & accept \\
LnFDIL does not Granger Cause LnTRADE & 0.0829 & accept \\
LnEXCH does not Granger Cause LnFDIL & 0.0014 & accept \\
LnFDIL does not Granger Cause LnEXCH & 0.6931 & refuse \\
LnUEP does not Granger Cause LnFDIL & 0.0206 & accept \\
LnFDIL does not Granger Cause LnUEP & 0.7470 & refuse \\
Ln R\&D does not Granger Cause LnFDIL & 0.0349 & accept \\
LnFDIL does not Granger Cause Ln R\&D & 0.4419 & refuse \\
\hline
\end{tabular}

Table 4 shows that China's economic development situation, exchange rate of USD against RMB, US trade deficit with China, the US gross domestic product, the US R\&D spending and US energy production are Granger causes of China's direct investment in the US.

\subsection{Conclusions and Recommendations}

Through theoretical analysis and empirical test, this article gets the result that the exchange rate of USD against RMB has a negative correlation with China's direct investment into the United States, while other factors have positive correlation during the post-crisis era. The growth of China's GDP has greatly enhanced the ability to carry out its foreign investment; The increase of US shale gas and other energy production has attracted Chinese capital flows to the United States; RMB appreciation positively lures Chinese enterprises with a higher purchasing power to carry out overseas investment in the US and has forced some companies to invest instead of exporting to US; The expansion of US trade deficit with China has led to trade disputes, prompting China through the expansion of direct investment in the US to ease trade friction; The increase of US gross domestic product and R\&D investment have attracted Chinese investment to a certain extent, and the aim for China to increase investment in the United States is to obtain a large consumer market and advanced technology. In short, the motivations of China's massive direct investment in the US during the post-crisis era include both push of the home country and the pull of the host country, which is in line with the current international and domestic environment.

According to the current situation of China's direct investment in the US, the paper proposes the following suggestions: First, encourage financial innovation, and make full use of the advantages of the exchange rate of USD against RMB, to carry out foreign direct investment, especially expanding investment scale in developed countries economies. Second, support private enterprises and improve the investment, to further explore the US market. More policy should be given to private enterprises, such as financial and other concessions, so as to make private enterprises become the real leader of the direct investment in the US, and thus eliminate the US government's "political concerns" to get more opportunities to enter the US market. Third, deepen the reform of the domestic economy, introduce high-tech talent, and promote the optimization and upgrading of domestic industrial structure. Change manufacturing-based industry situation of Chinese investment in the US, encourage other industries to invest in the US, and improve the investment structure of the United States. Moreover, achieving the diversification of the investment in the US and actively responding to the sensitive areas of investment are also important.

\section{Acknowledgments}

This paper is a phase achievement of social sciences project (10YJAGJW023) of the ministry of education chaired by Zongbin Zhang.

\section{References}

Bo, P. (2013). Influencing factors' Empirical Analysis of China's direct investment in US. Economic and Management Research, 84-88.

Cheng, L. K., \& Zihui, M. (2007). China's Outward FDI: Past and Future. SERUC Working Paper.

En, C., \& Fangfang, W. (2011). Influencing factors' Empirical Analysis of China's foreign direct investment. 
Business Economics and Management, 43-50.

Jian, S., \& Liang, Y. (2013). Barriers analysis of Chinese Direct Investment in the United States. Forecast, 1-6.

Jie, H. (2013). China's new trend, reasons and obstacles in the US direct investment. Chinese trade guide, 12-13.

Jieqin, S. (2014). The study on Chinese Corporations' Direct Investment in the US. Financial Sight, 74-75.

Jun, Z., \& Zhen, Z. (2012). Constraints Research of China's foreign direct investment under "going out" Strategy. Investment Research, 87-102.

Junjiang, L., Chunlong, X., \& Benye, S. (2013). The internal motivation, main obstacles and countermeasures of China's direct investment in US. Social Science, 73-77.

Ming, F. (2012). The trend, structure and barrier of China's direct investment in the United States. World Economics and Politics Forum, 107-120.

Noorbakhsh, F., \& Paloni, A. (2001). Structural Adjustment Programs and Growth Insub-Saharan Africa: The Importance of Complying with Conditionality. Economic Development and Cultural Chang, 479-509. http://dx.doi.org/10.1086/452512

Pingping, W. (2013). The influence on Sino-US trade imbalance by China's direct investment in the US. Capital University of Economics, Beijing.

Wenjing, L. (2014). The analysis on the factors of Chinese Direct Investment in the United States. Tianjin Normal University, Tianjin.

Yiling, H. (2011). Chinese multinationals Reverse Direct Investment in US which is driven by multifactor. Productivity, 88-90.

Yuanpeng, Z. (2015). A new development of China's direct investment in the United States since the global financial crisis. Modern Economic Research, 22-27.

Zhenyu, G., \& Yong, Z. (2015). Research on the influencing factors of China's direct investment in the US. Pacific Economic, 85-91.

\section{Copyrights}

Copyright for this article is retained by the author(s), with first publication rights granted to the journal.

This is an open-access article distributed under the terms and conditions of the Creative Commons Attribution license (http://creativecommons.org/licenses/by/3.0/). 